\title{
KANDIDIASIS PSEUDOMEMBRAN PADA LIDAH AKIBAT PEMAKAIAN OBAT KUMUR HEKSETIDIN SERTA PENATALAKSANAANNYA
}

Sri Hadiati

Bagian IImu Penyakit Mulut FKG UGM

\begin{abstract}
ABSTRAK
Latar Belakang: Candida albicans merupakan flora normal mulut yang paling sering menyebabkan penyakit infeksi. Jika flora normal rongga mulut terganggu keseimbangannya, misalnya karena terapi antibiotik, penyakit yang menyebabkan penurunan daya tahan tubuh (misalnya AIDS), kondisi lokal yang jelek, akan menyebabkan mikroorganisme oportunis bermultiplikasi dan menyebabkan terjadinya suatu infeksi. Tujuan: Melaporkan kasus kandidiasis pseudomembran pada lidah akibat pemakaian obat kumur serta penatalaksa-naannya. Kasus dan penatalaksanaannya: Kasus kandidiasis pada lidah sebagai akibat pemakaian obat kumur yang mengan-dung heksetidin $0,1 \%$ dalam jangka waktu lama yaitu sekitar satu bulan. Penatalaksanaan dengan pemberian suspensi nistatin $100.000 \mathrm{UI}$ topikal selama satu minggu cukup efektif mengatasi infeksi, medikasi diteruskan sampa dua minggu setelah gejala hilang. Kesimpulan: Pemakaian obat kumur dalam jangka waktu lama dapat menyebabkan infeksi oportunistik yaitu kandidiasis pseudomembran. Medikasi dengan nistatin topikal cukup efektif untuk mengatasi infeksi ini. Maj Ked Gi;, Desember 2011; 18(2): 178-181
\end{abstract}

Kata kunci: kadidiasis pseudomembran, obat kumur, heksetidin, penatalaksanaan

\section{ABSTRACT}

Background: Candida albicans is the most infectious oral normal flora. If oral normal flora disturbed such as excessive antibiotic therapy, immunodeficiency disease (AIDS), bad local condition will cause opportunistic microorganisms proliferation leading to infectious condition. Objective: to report lingual pseudomembraneous candidosis case caused by mouth rinse and its management. Case and Management: Lingual pseudomembraneous candidosis case caused by $0.1 \%$ hexitidine mouth rinse used for a long period about one month, was managed effectively by topical nystatin $100.000 \mathrm{IU}$ for one week, and medication must be continued for two week after clinical improvement. Conclusion: Long term usage of mouth rinse causes opportunistic infection of pseudomembraneous candidosis. Medication with topical nystatin effectively treat this infection. Maj Ked Gir, Desember 2011; 18(2): 178-181

Keywords: pseudomembraneous candidosis, mouth rinse, hexitidine, management

\section{PENDAHULUAN}

Kandida albikan merupakan jamur yang paling sering menyebabkan penyakit infeksi di mulut manusia. Pada keadaan normal populasi kandida albikan di rongga mulut sekitar $30 \%$ sampai $40 \%$ dari seluruh populasi. Jika flora normal rongga mulut terganggu keseimbangannya, misalnya karena terapi antibiotik, penyakit diabetes melitus, xerostomia, penurunan daya tahan tubuh (misalnya AIDS), keadaan ini akan menyebabkan mikroorganisme oportunis bermultiplikasi dan menyebabkan terjadinya suatu lesi ${ }^{1,2}$.

Kandidiasis oral akan membentuk lapisan putih keabu-abuan, curdy, superficial, jika dikerok jaringan di bawahnya meradang dan eritematous ${ }^{1}$ Pada infeksi ringan ulserasi hanya sedikit pada mukosa dan infiltrat inflamatori hanya superfisial subepitelial. Pada infeksi yang lebih berat akan menyebabkan ulserasi dan inflamasi yang lebih parah ${ }^{3}$.

Faktor-faktor predisposisi kandidiasis dapat berupa keadaan defisiensi imunologis, gangguan endokrin (diabetes melitus, hipoparatiroidisme, kehami-
Ian, hipoadrenalisme), terapi kortikosteroid, terapi antibiotik, terapi malignansi, xerostomia dan oral hygiene yang buruk'. Pada pejamu yang kompromais dan daya tahan tubuh rendah, infeksi kandida dapat meluas ke esofagus melalui saluran nasogastrik. Pada individu yang peka, penyebaran infeksi fungi dari membrana mukosa ke jaringan yang lebih dalam di rongga mulut, berpotensi berdifusi masuk ke sirkulasi darah sehingga membahayakan jiwa ${ }^{4}$.

Pasien dengan kandidiasis mengeluhkan sensasi terbakar, kadang-kadang nyeri pada mukosa yang terlibat. Mukosa yang terlibat menjadi peka terhadap makanan yang pedas ${ }^{5}$. Infeksi ini lebih sering terjadi pada wanita dan usia diatas 40 tahun. Limapuluh persen pasien mempunyai keluhan utama oral burning. Kandidiasis dapat juga terjadi sebagai akibat dari konsumsi antibiotik spektrum luas yang sering digunakan untuk mengobati sakit tenggorokan atau infeksi yang lain ${ }^{5,6}$.

Kandidiasis diklasifikasikan menjadi akut dan kronis, kandidiasis akut diantaranya adalah pseudomembran dan eritematous, sedangkan kan- 
didiasis kronis adalah hiperplastik dan eritematous. Kandidiasis eritematous dapat bersifat akut maupun kronis'. Infeksi oral kandidiasis pseudomembran terlihat sebagai deposit keputihan dengan patch eritematous pada mukosa atau berupa plaque agak meninggi berwarna putih lembut (creamy white). Keparahan penyakit ini dari regio tunggal, sampai keterlibatan difus berwarna putih pada beberapa mukosa sampai seluruhnya. Daerah sekitar atau diantara warna putih nampak area kemerahan. Psedomembran akan hilang jika dikerok dan meninggalkan area kemerahan kasar dan berdarah. Regio yang sering terjadi kandidiasis adalah mukosa pipi, vestibulum diikuti area dorsum lidah, palatum, gingiva dasar mulut dan bibir ${ }^{1,5,6}$.

Karakteristik tipe hiperplastik berupa plak putih yang tidak bisa hilang jika diusap. Lokasi yang paling sering terjadi diregio mukosa pipi, pada pasien terinfeksi HIV, kandidiasis hiperplastik sering terjadi pada komisura bibir ${ }^{1,6}$. Karakteristik tipe eritematous (atrofik) berwarna merah, intensitas warna bervariasi dari merah terang sampai merah muda. Biasanya terjadi pada perokok berat, lokasinya pada dorsum lidah dan palatum. Kandidiasis eritematous nampak sebagai spot area pada mukosa pipi, ini merupakan gambaran karakteristik pada pasien dengan infeksi HIV $^{1.6,7}$.

Diagnosis kandidiasis didasarkan atas perangai klinis, adanya hipa pada pemeriksaan usapan dengan kalium hidroksida, periodic acid-Shiff atau Gram stain ${ }^{3}$. Diagnosis banding adalah chemical burns, gangrenous stomatitis, infeksi superfisial bakteri, ulkus traumatik, ulkus nekrotik dan mucous patch $^{1,3}$. Prognosis baik pada kebanyakan kasus ${ }^{3,7}$.

Manajemen pasien dengan kandidiasis oral, pertama adalah identifikasi penyebab, faktor predisposisi maupun presipitasi dan kemudian mengeliminasinya, selanjutnya pemberian terapi dengan antifungi. Memperbaiki kondisi sistemik yang melatar belaka-ngi (diabetes, malnutrisi dan anemia), penghentian pemakaian antibiotik spektrum luas perlu direkomendasikan sebagai tindakan pertama. Daya tahan lokal dapat ditingkatkan dengan memperbaiki kebersihan mulut ${ }^{1,3}$.

Obat-obatan untuk terapi antifungal diantaranya adalah gentian violet, nistatin, amphotericin $B$, miconazole, clotrimazole, and ketoconazole. Nistatin and amphotericin merupakan obat standar untuk infeksi kandida selama 35 tahun. Obat ini baik digunakan secara topikal karena absorbsi di gastrointestinal jelek. Terapi harus diteruskan sampai 2 minggu sejak gejala hilang ${ }^{1,3,6}$.

Laporan ini membahas tentang kasus dari seorang wanita berusia 24 tahun yang secara klinis, laboratoris melalui pemeriksaan penunjang $\mathrm{KOH}$ test didiagnosis sebagai kandidiasis pseudomembran pada lidah, akibat dari pemakaian obat kumur yang mengandung heksetidin dalam jangka waktu lama.
Penyakit ini dapat terkontrol dengan pemberian nistatin dan penghentian pemakaian obat kumur.

\section{LAPORAN KASUS}

Seorang wanita berusia 24 tahun, mahasiswi datang ke RSGM Prof Soedomo FKG UGM dengan keluhan lidah terasa sakit, perih, panas kemranyas sehingga mengganggu pengecapan dan pengunyahan. Keadaan ini dirasakan selama tiga hari, waktu berkaca terlihat punggung lidahnya tertutup lapisan putih. Sebulan sebelumnya pasien menjalani operasi pengambilan gigi geraham bungsunya yang tidak bisa tumbuh, setelah operasi pasien mendapat obat amoksisilin yang diminum selama seminggu, analgetika dan obat kumur yang mengandung hexetidin. Pasien masih menggunakan obat kumur tersebut sampai saat ini karena takut bekas operasinya sakit.

Pemeriksaan vital signs, tensi $110 / 80 \mathrm{mmHg}$; nadi $65 \mathrm{x} /$ menit; pernafasan $20 \mathrm{x} /$ menit; suhu $36,6^{\circ}$ C. palpasi limfonodi submandibular kanan dan kiri tak teraba. Pada pemeriksaan intra-oral punggung lidah tampak dilapisi selaput berwarna putih susu yang berkurang jika diusap meninggalkan area kemerahan dan sakit. Indeks coated tongue $60 \%$ (gambar 1), tak ada lesi lain di mulut. Hasil pemeriksaan laboratorim darah rutin dalam batas normal, hasil test $\mathrm{KOH}$ positip. Berdasarkan pemeriksaan subyektif dan obyektif pasien didiagnosis menderita kandidiasis tipe pseudomembran pada punggung lidah.

Perawatan yang dilakukan, pasien diberi medikasi topikal suspensi nistatin 100.000 UI, 4 kali sehari dua tetes. Kepada pasien dijelaskan bahwa lapisan putih dipunggung lidah adalah infeksi jamur akibat pemakaian obat kumur yang mengandung heksetidin dalam jangka waktu lama. Pasien dianjurkan untuk menghentikan pemakaian obat kumur, menjaga kebersihan mulutnya dengan menyikat gigi dan membersihkan lidah setelah menyikat gigi, meng-gunakan obat tetes anti jamur dengan cara diteteskan ke punggung lidah 2 tetes kemudian diratakan dengan lidah 4 kali sehari.

Pada waktu kontrol 1 minggu kemudian, rasa nyeri pada lidah sudah tidak dirasakan lagi, sudah tak ada gangguan pengecapan maupun pengunyahan, pada pemeriksaan intraoral tidak ada lagi lapisan putih yang menutupi punggung lidah (gambar 2), ini menunjukkan bahwa kandidiasis pseudomembran sudah sembuh. Pasien diminta untuk terus menggunakan obatnya selama 2 minggu dan menjaga kebersihan mulut dengan menyikat gigi dan membersihkan lidahnya.

Evaluasi 2 minggu kemudian tidak ada keluhan dan tidak ada kekambuhan. Pasien diedukasi agar tetap menjaga kebersihan dan kesehatan mulutnya, dan jangan menggunakan obat kumur lebih dari 5 hari. 


\section{PEMBAHASAN}

Mikroflora secara alami berada di dalam rongga mulut mulai bayi, masa anak-anak, selalu berubah selama masa kehidupan manusia tergantung pada lingkungan dan faktor-faktor yang mempengaruhinya. Jika komunitas mikrobial terganggu, maka dapat berubah menjadi patogen menyebabkan karies penyakit periodontal dan infeksi. Penelitian terbaru menunjukkan bahwa mikroorganisme pada plak mememegang peranan dalam penyakit sistemik, diantaranya diabetes, dan atherosklerosis. Plak dental sekarang diketahui membentuk biofilm mikrobial kompleks yang mengandung lebih dari 600 spesies bakteri di dalam rongga mulut ${ }^{8}$.

Mikroflora alamiah sangat diperlukan untuk perkembangan fisiologi normal dari pejamu dan berperan sebagai pertahanan pejamu terhadap mikroorganisme eksogen. Komposisi mikroflora bervariasi dari permukaan ke permukaan lain di mulut (misalnya gigi, mukosa) dan dari sisi permukaan yang spesifik (misalnya fissur, gingival crevice) merupakan tempat / habitat dari suatu mikroorganisme tertentu membentuk koloni dan menetap. Komposisi komunitas mikroflora stabil dari waktu ke waktu, membentuk homeostasis mikroflora. Stabilitas ini tidak mengindikasikan hubungan yang pasif dengan pejamu, tetapi merupakan balans dinamik diantara komponen dari spesies mikroorganisme. Stabilitas dapat terganggu oleh perubahan lingkungan atau perubahan gaya hidup orang yang terjadi selama kehidupan individu, meliputi perubahan dalam diet, medikasi, merokok, curah saliva, pemakaian gigi palsu. Kondisi kesehatan tubuh dan lainnya dapat menyebabkan pertumbuhan yang berlebihan dari mikroflora komponen minoritas serta merupakan predisposisi terjadinya penyakit di tempat tersebut. Respon imun dapat menurun pada usia lanjut, dimana mengakibatkan kolonisaśi eksogenous terkadang mikroorganisme patogen. Mikroflora oral dapat berubah menjadi patogen dan menyebabkan penyakit serius pada tubuh manusia. Oleh karena itu manajemen oral health care sangat perlu untuk menjaga homeostasis mikrobial ${ }^{8,9}$.

Pada kasus diagnosis sebagai kandidiasis pseudomembran akibat infeksi oportunistik kandida albikan yang ditetapkan berdasarkan atas riwayat, tampilan klinis pada lidah yang merupakan selaput yang berwarna putih jika dikerok meninggalkan area eritematous yang dirasakan sakit oleh pasien serta pemeriksaan penunjang dengan tes $\mathrm{KOH}$ positip adanya gambaran hipa. Hasil pemeriksaan darah rutin dalam batas normal, berarti tidak ada faktor sistemik yang melatar belakangi infeksi kandida ini.

Pada anamnesis terdapat riwayat penggunaan obat kumur mengandung heksetidin $0,1 \%$ dalam jangka waktu lama ( \pm 1 bulan), setelah pasien menjalani operasi gigi impaksi. Heksetidin adalah derivat pirimidin yang bersifat antiseptik. Komposisi komunitas mikrobial stabil dari waktu ke waktu, membentuk homeostasis mikrobial. Stabilitas merupakan balans dinamik diantara komponen spesies dan pejamu ${ }^{9}$. Stabilitas dapat terganggu oleh perubahan lingkungan. Antiseptik menekan pertumbuhan sebagian mikroflora, sehingga homeostasis mikroflora terganggu, mikroflora oportunis menjadi lebih dominan populasinya dan menjadi patogen, pada kasus ini kandida albikan meningkat populasinya dan menjadi patogen, menimbulkan penyakit infeksi kandidiasis pseudomembran.

Pada kasus ini perawatan dilakukan dengan edukasi dan medikasi, pasien diberi penjelasan tentang penyakit yang dideritanya, dan diminta untuk menghentikan pemakaian obat kumur yang mengandung heksetidin, menjaga kebersihan mulutnya dengan menyikat gigi dan membersihkan lidah serta memakai obat sesuai aturan yang di berikan. Pasien diberi medikasi suspensi nistatin 100.000 UI diteteskan $2 \mathrm{ml}, 4$ kali sehari sesudah menyikat gigi dan sebelum tidur. Hasil perawatan cukup efektif untuk menekan pertumbuhan kandida albikan, hal ini terlihat secara klinis pada hari ke 7 lapisan putih pada punggung lidah sudah tidak nampak lagi dan keluhan rasa sakit pada lidah yang dirasakan pasien sudah hilang.

Sesuai dengan aturan penatalaksanaan kandidiasis, maka medikasi kandidiasis harus diteruskan selama 2 minggu setelah gejala hilang ${ }^{3}$, maka pasien diminta tetap menggunakan suspensi nistatin topikal dan menjaga kebersihan rongga mulut. Pada kontrol dua minggu kemudian tidak ada kekambuhan, tidak ada rasa sakit, punggung lidah bersih tidak ada lapisan putih.

\section{KESIMPULAN}

Pemakaian obat kumur dalam jangka waktu lama dapat menyebabkan infeksi oportunistik yaitu kandidiasis pseudomembran. Medikasi dengan suspensi nistatin topikal selama satu minggu cukup efektif untuk mengatasi infeksi, medikasi diteruskan sampai dua minggu setelah gejala hilang.

\section{DAFTAR PUSTAKA}

1. Regezi JA, Sciubba JJ, \& Jordan CK: Oral Pathology Clinical Pathologic Correlations. $4^{\text {the }}$ ed., W.B. Saunders Co, St Louis, Missouri, 2003, 100-101.

2. Akpan A \& Mornan R: Oral Candidiasis. J Postgrad Med . 2002 Aug;78 (922) :455-9.

3. Zunt SL: Oral Candidiasis diagnosis dan Treatment. The Journal Of Practical Hygiene, September/Oktober 2000; 31-36.

4. Kokeguchi S\& Maeda H: Oral Microflora and Their Relation to Health and Disease. Foods Food Ingredients J. Jpn., 2005, Vol. 210, No.4.

5. Lynch DP: Oral candidiasis : History, classification, and clinical presentation. J.Oral Surg, Oral Med, Oral Pathol, 1994, 78( 2): 189-193. 
6. Fotos PG, Steven D, Vincent SD, John W, \& Hellstein JW: Oral candidosis: Clinical, historical, and therapeutic features of 100 cases. J.Oral Surg, Oral Med, Oral Pathol, 1992, 74( 1): 41-49.

7. Bergman SA: Fungal, Viral and Protozoal Infections of the Maxillofacial Region. dalam Topazian RG, Goldberg $\mathrm{MHH}$, \& Hupp JR, Oral and Maxillofacial Infections. $4^{\text {the }}$ d., W.B. Saunders Co. Philadelphia, Pennsylvania. 2002, 248-249.

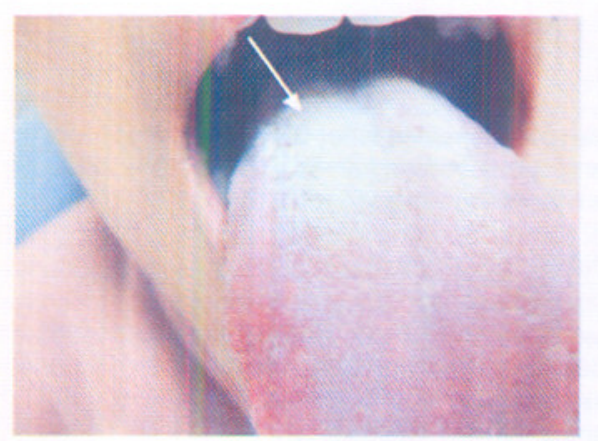

Gambar 1: Kandidiasis pseudomembran pada dorsal lidah
8. Marsh PD \& Percival RS: The oral microflora--friend or foe? Can we decide? Int Dent J. 2006 Aug;56(4 Suppl 1):233-9.

9. Jenkinson HF \& Douglas LJ: Interactions between Candida Species and Bacteria in Mixed Infections. Diunduh dari http://www.ncbi.nlm.nih.gov/books/ NBK2486 tanggal 8/03/2011.

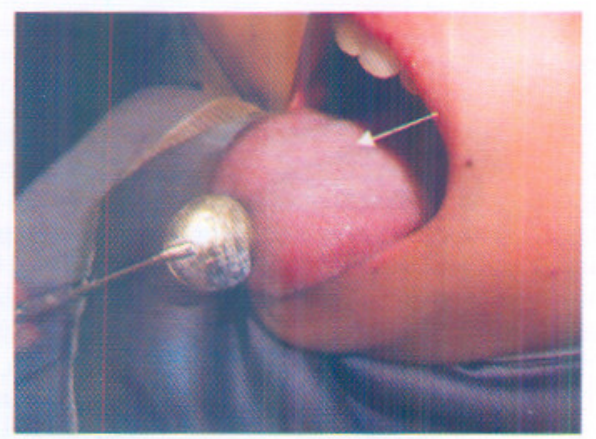

Gambar 2: Setelah perawatan selama 1 minggu, candidiasis pseudo membran sudah sembuh 